\title{
INSTITUTIONAL DIFFERENCES OF INFORMATION CONTENT ON VOLUNTARY EARNINGS RELEASES IN THE U.S. AND CANADA
}

\author{
Ronald Stunda \\ Valdosta State University • Valdosta, Georga
}

\section{ABSTRACT}

Historically, Canadian laws have created a less litigious environment than those of the U.S. This changed in 1998 with the passage of the Securities Litigation Uniform Standards Act (SLUSA), and in 2000 with the passage of Regulation Full Disclosure (Regulation FD). The intent of these acts were to not only encourage more U.S. firms to release voluntary earnings forecasts, but to offer protection for such disclosures against lawsuits, similar to laws in Canada. In addition, with the advent of International Financial Accounting Standards (IFRS), voluntary earnings releases play a bigger role, in increased frequency and revision of forecasts. Since Canada requires the use of IFRS in financial reporting, it serves as a good base of comparison of what may be to come in the U.S. These types of differences comprise what can be characterized as institutional differences.

This study finds that Canadian managers tend to issue voluntary earnings forecasts more frequently across the board than their U.S. counterpart, even after the interdiction of SLUSA and Regulation FD in the U.S. In addition, the Canadian forecasts tend to be more precise than those offered by U.S. managers. On the surface, it appears that the SLUSA and Regulation FD have not completely achieved their goal of creating greater and more informative voluntary earnings disclosures in the U.S., but in addition, IFRS adoption in Canada may have also led to the increased frequency and accuracy of earnings forecasts.

\section{INTRODUCTION}

While the Canada Revenue Agency does not specify that financial statements must be prepared following any particular type principles or standards, the Accounting Standards Board of Canada (AcSB) requires reporting entities to use International Financial Reports Standards (IFRS) in the preparation of all interim and annual financial statements. This is important for two reasons: 1. Canada is the closest North American country to the U.S. to adopt IFRS reporting standards, and therefore serves as a good standard for what may be on the horizon for U.S. firms, 
2: IFRS adoption has an impact on the increased frequency of both new and revised voluntary earnings forecasts [Balakrihnan, Li, and Yang (2014)]. As the U.S. inches closer to an IFRS basis (the latest IFRS-based adoption regarding revenue recognition taking place in 2015), it behooves accounting researchers to evaluate the impact of increased voluntary financial disclosures in the U.S. with the potential advent of IFRS looming in the background. In addition, the mechanics of how voluntary forecast issues in Canada may form a basis for how we may address voluntary releases in the U.S. for both the near term and long term future.

The international accounting literature in general recognizes the existence of different accounting models. Frank (1979) and Nair and Frank (1980) classify countries' financial reporting practices built around the contrast between commonlaw and code-law systems, and any variations within.

Recent accounting studies examine institutional factors that shape and characterize the U.S. accounting system, and compare that system with other countries. Guenther and Young (2000) find U.S. accounting earnings more reflective of underlying economic reality due to their institutional differences. Ball, Kothari, and Robin (2000) argue that the difference between common-law and code-law systems manifests in the dichotomy of shareholder and stakeholder corporate governance models. The shareholder governance model, they find, resolves the information asymmetry through public disclosures, while the stakeholder model does it through private communication.

Many extant studies compare the differences in accounting models between code-law and common-law countries [Joliet and Muller (2009), Jacobsen and Aaker (1993), Harris et al (1993), Bodnar and Weintrop (1997), Barth and Clinch (1996) and Bodnar et al (2003)]. Very few studies, however, assess accounting differences of countries within those two groups. One such likely comparison is that of the two largest economic powers in the western hemisphere, the U.S. and Canada. In recent years, Canada has undergone tremendous economic growth, fueled by oil production. Its percentage increase in net exports now outpaces the U.S., its GDP exceeds that of the U.S., it has greater wealth per capita (\$51,147 versus the U.S.'s \$48,147), and the Canadian dollar has just about pulled even in value to the U.S. dollar. Both are common-law countries and trading partners, but little research has been done on the difference between the two countries from an accounting perspective. One such area where differences between these two countries may be explored is that of voluntary earnings forecasts.

In the area of voluntary earnings disclosures, prior research finds that managers release information that is unbiased relative to subsequently revealed earnings 
and that tends to contain more bad news than good news [Baginski et al (1994), and Frankel (1995)]. Such releases are also found to contain information content [Patell (1976), Waymire (1984), and Pownell and Waymire (1989)]. Although forecast release is costly, credible disclosure will occur if sufficient incentives exist. These incentives include bringing investor/manager expectations in line [Ajinkya and Gift (1984)], removing the need for expensive sources of additional information [Diamond (1985)], reducing the cost of capital to the firm [Diamond and Verrechia (1987)], and reducing lawsuits [Lees (1981)].

Other studies show that managers are more likely to issue voluntary forecasts in a less litigious environment [Frost (2001), Johnson et al (2002)], while another [Baginski (2002)] finds that there are potential legal environment differences between the U.S. and Canada when issuing earnings forecasts. Clarkson and Simunic (2004) note that unlike the U.S., courts in Canada generally require unsuccessful plaintiffs to pay the costs of a successful defendant. Also, because plaintiffs have no absolute right to a jury trial in Canada, judges hear technical cases and are less likely to award large settlements. In addition, Canadian provinces do not permit trial lawyers to work on a contingency basis. Also, it is much more difficult to bring a class action suit in Canada. All of these differences in the two legal systems create a natural environment in which voluntary earnings releases may be perceived differently. This situation creates an opportunity to evaluate two neighboring commonlaw countries from an accounting perspective focusing on the release of voluntary earnings forecasts, and the information content they contain. This comparison becomes even more relevant given the passage of the Securities Litigation Uniform Standards Act (SLUSA) in 1998 when the U.S. Congress attempted to protect U.S. firms issuing earnings forecasts from litigation, and the continuing effort by the Financial Accounting Standards Board (FASB) to get U.S. firms to release more voluntary forecasts for the benefit of the investor. This was further enhanced in 2000 by Congressional passage of Regulation Fair Disclosure which also attempts to shield such forecasts.

\section{HYPOTHESIS DEVELOPMENT}

Three hypotheses are tested. First, King et al (1990) finds that forward looking information disclosure in the U.S. increases the firm's exposure to legal liability. Balakrishnan et al (2014) find that Canadian firms have adopted IFRS and are therefore more likely to issue voluntary forecasts. For these reasons many U.S. firms, by comparison, have not exhibited a desire to issue voluntary forecasts on a consistent 
and on-going basis. The first hypothesis, stated in the alternative form is:

H1: Canadian firms, faced with institutional differences such as a less-litigious legal environment, and the requirements of IFRS engage in more voluntary earnings forecasts relative to U.S. firms.

The second hypothesis, also stated in the alternative form, relates to previous studies that indicate U.S. firms are less likely to issue voluntary forecasts during good news periods for fear of litigation:

H2: Canadian firms, faced with institutional differences, engage in voluntary forecast releases that are less-related to earnings than U.S. firms.

The third hypothesis, stated in the alternative form, centers around the notion that as voluntary forecasts are made with greater frequency, they should also tend to exhibit greater accuracy over the long term:

H3: Canadian firm faced with institutional differences, engage in more precise forecasting of earnings information.

\section{RESEARCH DESIGN}

The sample consists of all quarterly and annual earnings estimates made during the period 1999-2013 (1st quarter). The reason that this time period was chosen is because SLUSA and Regulation FD passage took place during this period (1998 and 2000 respectively). These are the acts that, in essence, provided litigation relief for U.S. firms filing voluntary earnings forecasts. These acts presumably permit U.S. firms similar legal protection as Canadian firms, thus facilitating more accurate comparison. In addition, in 2006, Canadian firms, as required by the Canada Revenue Agency, began to report financial information under an IFRS basis. As a result, the numbers of voluntary forecasts tended to grow [Balakrishnan et al (2014)]. The sample used in the study takes these events and their dates into consideration as inclusive of the overall sample. The sample met the following criteria: 1) The voluntary earnings forecast was recorded by the Dow Jones News Retrieval Service (DJNRS). The Canadian exchanges list the Dow Jones as a preferred means of disclosure. 2) Earnings data was obtained from Compustat. The overall sample consists of firms which made at least one management earnings forecast during the period 1999-2013 (1st quarter). All American exchanges (NYSE, NASDAQ, OTC, 
ASE) and all Canadian exchanges (Toronto, Vancouver, Montreal, Regional, Nonlisted Canadian) were included in the sample. Table 1 provides the summary of the sample used in the study.

Table 1

Study Sample Summary

\begin{tabular}{|l|c|c|c|}
\hline & U.S. & Canadian & Total \\
\hline $\begin{array}{l}\text { Firm-years available on Compustat } \\
\text { Firm-quarters available on Compustat } \\
\text { Total firm years/quarters sample }\end{array}$ & $\begin{array}{c}158,297 \\
\frac{482,216}{640,513}\end{array}$ & $\begin{array}{c}21,223 \\
\frac{79,228}{100,451}\end{array}$ & $\begin{array}{c}179,520 \\
\frac{561,444}{740,964}\end{array}$ \\
\hline & & & \\
\hline $\begin{array}{l}\text { Forecasts identified by DJNRS } \\
\text { Loss due to Compustat requirement }\end{array}$ & $\begin{array}{c}7,213 \\
(542)\end{array}$ & $\begin{array}{c}3,801 \\
(271)\end{array}$ & $\begin{array}{c}11,014 \\
(813)\end{array}$ \\
\hline Final forecast sample & $\frac{6,671}{3,530}$ & $\frac{10,201}{10}$ \\
\hline
\end{tabular}

\section{TEST OF HYPOTHESES}

Table 1 reports that 179,520 firm-years and 561,444 firm-quarters are available on Compustat for the sample total of potential voluntary forecast periods from 1999-2013 (1st quarter). A total of 6,671 U.S. forecasts are made by 750 firms (8.90 per firm over $14+$ years) while 3,530 forecasts are made by 275 Canadian firms (12.84 per firm over $14+$ years).

\section{FORECAST FREQUENCY AND GOOD VERSUS BAD NEWS FORECASTS}

To test $\mathrm{H} 1$ and $\mathrm{H} 2$, a logistic regression model is used similar to the one employed in Baginski et al (2002). It uses a combined sample of Canadian and U.S. firms across all potential forecasting periods $(n=740,964)$ :

FORECAST $_{\text {it }}=\mathrm{a}_{0}+\mathrm{a}_{1} \operatorname{DESIGN}_{\mathrm{it}}+\mathrm{a}_{2}$ CANADA $_{\mathrm{it}}+\mathrm{a}_{3}$ CANADA $_{\mathrm{it}}$ x $\triangle$ ESIGN $_{\mathrm{it}}+$ $\mathrm{a}_{4} \mid \Delta$ EARNINGS $_{\mathrm{it}} \mid+\mathrm{a}_{5}$ LSIZE $_{\mathrm{it}}+\mathrm{a}_{6}$ REGULATE $_{\mathrm{it}}+\mathrm{a}_{7}$ HIGHTECH $_{\mathrm{it}}+€_{\mathrm{it}}$

Where:

FORECAST $_{\text {it }} \quad=\quad 1$ if the firm issued a voluntary earnings forecast during the period 0 otherwise. 


\begin{tabular}{|c|c|c|}
\hline$\Delta \mathrm{ESIGN}_{\text {it }}$ & $=$ & $\begin{array}{l}\text { the sign of the earnings change } 1,1 \text { if } \geq 0 \text { (good } \\
\text { news), and } 0 \text { if }<0 \text { (bad news). }\end{array}$ \\
\hline CANADA $_{\text {it }}$ & $=$ & $\begin{array}{l}1 \text { if the potential forecasting period relates to a } \\
\text { Canadian firm, } 0 \text { otherwise. }\end{array}$ \\
\hline $\mid \Delta$ EARNINGS $_{i \mathrm{t}} \mid$ & $=$ & the absolute value of $\triangle$ EARNINGS $_{\text {it }}$ \\
\hline LSIZE $_{\text {it }}$ & $=$ & $\begin{array}{l}\text { size of the firm using the natural log of the market } \\
\text { value of equity at the beginning of the period. }\end{array}$ \\
\hline REGULATE $_{\text {it }}$ & $=$ & 1 if the firm is in a regulated industry, and 0 otherwise. \\
\hline HIGHTECH $_{\text {it }}$ & $=$ & $\begin{array}{l}1 \text { if the firm is in a high-technology industry, and } \\
0 \text { otherwise. }\end{array}$ \\
\hline
\end{tabular}

Figure 1 maps the coefficients in Equation (1) to H1 and H2. Column (1) lists the coefficient sums in earnings increase periods (i.e., good news, $\triangle \mathrm{ESIGN}_{\mathrm{it}}=$ 1) for Canadian firms in row 1 and for U.S. firms in row 2. Column (2) provides analogous coefficients for earnings decrease periods (i.e., bad news, $\Delta \mathrm{ESIGN}_{\mathrm{it}}=0$ ). The last row indicates the difference between countries in the propensity to issue forecasts in periods of good news $\left(\mathrm{a}_{2}+\mathrm{a}_{3}\right)$, and bad news $\left(\mathrm{a}_{2}\right)$. Hypothesis 1 predicts that Canadian firms issue more forecasts, thus, both sets of coefficients are expected to be positive $\left(a_{2}+a_{3}>0, a_{2}>0\right)$.

Column (3) in Figure 1 provides coefficients associated with differences between good and bad news periods (i.e., "sign-related" forecast behavior) in Canada (row 1 ) and the U.S. (row 2). The last row in the column shows that the coefficient $\mathrm{a}_{3}$ measures the differences between countries in sign-related forecasting behavior. If legal-liability-created asymmetric forecast disclosure incentives in the U.S. lead to more forecasts in bad news periods, then the expectation is that a $<0$. Hypothesis 2 predicts $\mathrm{a}_{3}>0$, indicating that Canadian managers are less likely to skew forecast disclosures toward bad news periods.

Following Baginski, Hassel, and Kimbrough (2002), control variables are established for; volatility $\left(\mid \Delta\right.$ EARNINGS $\left._{i t}\right)$, firm size (LSIZE $\mathrm{it}_{\mathrm{it}}$ ), whther the firm is in a regulated industry and therefore requires fewer forecasts (REGULATE ${ }_{i t}$ ), and whether the firm is in a high tech field which is riskier and therefore requires more forecasts $\left(\mathrm{HIGHTECH}_{\mathrm{it}}\right.$ ). 


\section{Figure 1}

\section{Mapping Equation (1) into Hypothesis Tests}

\begin{tabular}{|l|l|l|l|}
\hline & $\begin{array}{c}\text { Good News Period } \\
\Delta \text { ESIGN }_{\text {it }}=\mathbf{1}\end{array}$ & \multicolumn{1}{|c|}{$\begin{array}{c}\text { Bad News Period } \\
\Delta \text { ESIGN }_{\text {it }}=\mathbf{0}\end{array}$} & \multicolumn{1}{c|}{$\begin{array}{c}\text { Difference } \\
\text { Across Sign }\end{array}$} \\
\hline $\begin{array}{l}\text { Canadian } \\
\text { (CANADA = 1) }\end{array}$ & $\mathrm{a}_{0}+\mathrm{a}_{1}+\mathrm{a}_{2}+\mathrm{a}_{3}$ & $\mathrm{a}_{0}+\mathrm{a}_{2}$ & $\mathrm{a}_{1}+\mathrm{a}_{3}$ \\
\hline $\begin{array}{l}\text { U.S. } \\
\text { (CANADA = 1) }\end{array}$ & $\mathrm{a}_{0}+\mathrm{a}_{1}$ & & $\mathrm{a}_{1}$ \\
\hline $\begin{array}{l}\text { Difference } \\
\text { Between } \\
\text { Countries (row } \\
1-\text { row 2) }\end{array}$ & $\begin{array}{l}(\mathrm{H} 1 \text { test during good } \\
\text { news periods): } \\
\mathrm{a}_{2}+\mathrm{a}_{3}>0\end{array}$ & $\begin{array}{l}(\mathrm{H} 1 \text { test during bad } \\
\text { news periods): } \\
\mathrm{a}_{2}>0\end{array}$ & $\begin{array}{l}\text { Difference between } \\
\text { countries in sign- } \\
\text { related behavior }(\mathrm{H} 2): \\
\mathrm{A}_{3}>0\end{array}$ \\
\hline
\end{tabular}

\section{FORECAST PRECISION}

King et al (1990) argue that U.S. managers are concerned about potential litigation if a forecast turns out to be inaccurate. Accordingly, researchers have argued that, when faced with perceived higher expected litigation costs, U.S. managers will issue less-precise forecasts (i.e., range, minimum, maximum or general impression forecasts instead of point forecasts). Empirical evidence shows that this is consistent among U.S. firms [Skinner (1994), Baginski and Hassell (1997), Bamber and Cheon (1998)].

The Canadian legal system has historically exacted lower legal penalties for inaccuracy than the U.S. legal system. In addition, with the advent of IFRS adoption in 2006, Canadian firms have issued more financial forecasts, in addition to issuing more revised forecasts. Canadian managers, therefore, should have the ability to issue more precise management forecasts (H3) and to make forecast precision choices that are less likely to depend on whether the firm is performing poorly during the period (H2). To test these hypotheses, the following ordered logistic regression model is used for a pooled sample of all forecasts issued by U.S. and Canadian firms $(\mathrm{n}=10,201)$.

PRECISE $_{\mathrm{i}}=\mathrm{b}_{0}+\mathrm{b}_{1} \Delta$ ESIGN $_{\mathrm{i}}+\mathrm{b}_{2}$ CANADA $_{\mathrm{i}}+\mathrm{b}_{3}$ CANADA $_{\mathrm{i}} \times \Delta$ ESIGN $_{\mathrm{i}}+\mathrm{b}_{4}$ LSIZE $_{\mathrm{i}}$ $+\mathrm{b}_{5}$ REGULATE $_{\mathrm{i}}+\mathrm{b}_{6}$ HIGHTECH $_{\mathrm{i}}+\mathrm{b}_{7}$ HORIZON $_{\mathrm{i}}+\mathrm{v}_{\mathrm{i}}$ 
Management forecast precision is measured using an ordinal coding scheme that assigns the highest value to the most precise forecasts. PRECISE equals 3, 2, 1 , and 0 for point, closed interval, open interval, and general impression forecasts, respectively. Hypothesis 3 predicts that Canadian firms will issue more precise forecasts because historically, the legal penalties for inaccuracy are smaller, and the requirements of IFRS. For earnings decreases, this suggests that b2 $>0$, and for earnings increases, it suggests that $b_{2}+b_{3}>0$. If fear of legal liability, and noncompliance with IFRS leads U.S. firms to issue less precise forecasts when the firm is performing poorly, then $\mathrm{b} 1>0$. Hypothesis 2 predicts that Canadian forecast precision is less skewed toward poor performance than is U.S. forecast precision $\left(b_{3}<0\right)$.

Based on Baginski, Hassell, and Kmbrough (2002), controls are established for; firm size (LSIZE), representing the natural log of the market value of equity at the beginning of the period, if the firm belongs to a regulated utility (REGULATE) since regulated bodies are required to produce a large amount of financial information, thus forecasts are deemed unnecessary, if the firms are high-technology (HIGHTECH) since they are riskier and may require more forecast data, and the number of days between the forecast date and the end of the period being forecast (HORIZON) since the shorter the period between these dates, the more precise the forecast.

\section{RESULTS}

\section{Forecast Frequency and Good Versus Bad News Forecasts}

Table 2 describes variable distributions for the sample of 740,964 potential forecasting periods and 10,201 voluntary earnings forecasts. This table shows that forecast frequency is only $1.0415 \%$ for U.S. firms and $3.5142 \%$ for Canadian firms. Table 2 also indicates that Canadian firms release voluntary management earnings forecasts $60 \%$ of the time when the earnings information is good news compared with $40 \%$ of the time for their U.S. counterparts. With respect to precision of the forecast, Table 2 shows that Canadian firms are more likely to issue point forecasts (most precise type) $58 \%$ of the time versus $24 \%$ for U.S. firms. 
Table 2

Variable Distributions for 1999-2013 (1st quarter); Sample of 740,964

Potential Forecasting Periods $(n=100,451$ Canadian and $n=640,513$ U.S.); and sample of 10,201 Management Earnings Forecasts $(n=3,530$ Canadian and $n=6,671$ U.S.)

\begin{tabular}{|c|c|c|c|}
\hline & Good News Periods & Bad News Periods & Total \\
\hline & $\left(\triangle \mathrm{ESIGN}_{\mathrm{it}}=1\right)$ & $\left(\triangle \mathrm{ESIGN}_{\mathrm{it}}=0\right)$ & \\
\hline \multicolumn{4}{|l|}{$\begin{array}{l}\text { Potential Forecast } \\
\text { Periods: }\end{array}$} \\
\hline U.S. Firms & 269,015 (40\%) & 371,498 (60\%) & 640,513 \\
\hline Canadian Firms & $56,252(56 \%)$ & 44,199 (44\%) & 100,451 \\
\hline Total & 325,267 & 415,697 & 740,964 \\
\hline \multicolumn{4}{|l|}{$\begin{array}{l}\text { Management } \\
\text { Earnings Forecasts: }\end{array}$} \\
\hline U.S. Firms & 2,668 (40\%) & $4,003(60 \%)$ & 6,671 \\
\hline Canadian Firms & 2,118 (60\%) & 1,412 (40\%) & 3,530 \\
\hline Total & 4,786 & 5,415 & 10,201 \\
\hline \multicolumn{4}{|l|}{$\begin{array}{l}\text { Forecast Frequency } \\
\text { Rates In Potential } \\
\text { Forecast Periods: }\end{array}$} \\
\hline U.S. Firms & $.9918 \%$ & $1.0775 \%$ & $1.0415 \%$ \\
\hline Canadian Firms & $3.7652 \%$ & $3.1946 \%$ & $3.5142 \%$ \\
\hline \multicolumn{4}{|l|}{$\begin{array}{l}\text { Management } \\
\text { Forecast Type: }\end{array}$} \\
\hline & U.S. Firms & Canadian Firms & Total \\
\hline Point & $1,601(24 \%)$ & 2,047 (58\%) & 3,648 (36\%) \\
\hline Range & 1,667 (25\%) & 635 (18\%) & 2,302 (23\%) \\
\hline Minimum & $1,734(26 \%)$ & 706 (20\%) & $2,440(24 \%)$ \\
\hline Maximum & 867 (13\%) & $141(4 \%)$ & $1,008(9 \%)$ \\
\hline General Impression & 802 (12\%) & $1(0 \%)$ & $803(8 \%)$ \\
\hline Total & 6,671 (100\%) & 3,530 (100\%) & 10,201 (100\%) \\
\hline
\end{tabular}

Table 3 presents the Equation (1) logistic regression tests of $\mathrm{H} 1$ and $\mathrm{H} 2$. Coefficient $a_{2}$ is significantly positive $(p=0.001)$, so Canadian firms are more likely to issue voluntary earnings forecasts during bad news periods relative to U.S. firms. The sum coefficients $\mathrm{a}_{2}+\mathrm{a}_{3}$ is also significant $(\mathrm{p}=0.002)$, indicating that Canadian 
firms are also more likely to issue voluntary earnings forecasts during good news periods. These results support H1's prediction that the possibility of institutional differences such as lower legal liability and the adoption of IFRS in Canada may lead to more forecast disclosures during both good and bad news periods. These results are also consistent with findings on forecast frequency rates in Table 2.

With respect to $\mathrm{H} 2$, the results are also consistent with expectations. U.S. firm behavior is as expected, coefficient al is significantly negative $(p=0.005)$. This indicates more forecast disclosure in bad news periods relative to good news periods. Coefficient $\mathrm{a}_{3}$, which measures the difference between U.S. and Canadian sign-related behavior, is significantly positive $(\mathrm{p}=0.001)$ indicating that Canadian forecasts occur more often in good news periods. These results are also consistent with findings in Table 2. These differences between Canadian and U.S. forecasting behavior arise even after controlling for the absolute value of the earnings surprise $\left(a_{4}\right.$ is significantly negative with a p-value of 0.006$)$, firm size $\left(a_{5}\right.$ is significantly positive with a p-value of 0.001$)$, regulated industry membership ( $a_{6}$ is significantly negative with a $p$-value of 0.001 ), and high tech industry membership ( $a_{7}$ is insignificantly different from 0 ).

\section{Table 3}

Management Earnings Forecast Frequency in the U.S. and Canada FORECAST $_{i t}=a_{0}+a_{1} \Delta$ ESIGN $_{i t}+$ a2CANADA $_{i t}+a_{3}$ CANADA $_{i t} x \Delta$ ESIGN $_{i t}$

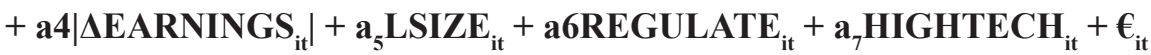

\begin{tabular}{|l|l|c|}
\hline \multicolumn{1}{|c|}{$\begin{array}{c}\text { Independent Variable } \\
\text { (Coefficient) }\end{array}$} & \multicolumn{1}{|c|}{ Expected Sign } & \multicolumn{1}{c|}{$\begin{array}{c}\text { Coefficient Estimate } \\
\text { (p-value) }\end{array}$} \\
\hline Intercept $\left(\mathrm{a}_{0}\right)$ & none predicted & $-5.913(0.223)$ \\
\hline$\triangle$ ESIGN $\left(\mathrm{a}_{1}\right)$ & negative & $-0.221(0.005)$ \\
\hline CANADA $\left(\mathrm{a}_{2}\right)$ & positive $(\mathrm{H} 1$ for bad news) & $0.522(0.001)$ \\
\hline CANADA $\times \triangle$ ESIGN $\left(\mathrm{a}_{3}\right)$ & positive $(\mathrm{H} 2)$ & $0.612(0.001)$ \\
\hline$\left|\triangle E A R N I N G S\left(a_{4}\right)\right|$ & negative & $-0.351(0.006)$ \\
\hline LSIZE $\left(a_{5}\right)$ & positive & $0.480(0.001)$ \\
\hline REGULATE $\left(a_{6}\right)$ & negative & $-1.321(0.001)$ \\
\hline HIGHTECH $\left(a_{7}\right)$ & none predicted & $-0.129(0.162)$ \\
\hline Coefficients $\mathrm{a}_{2}+\mathrm{a}_{3}$ & positive $(\mathrm{H} 1$ for good news) & $0.857(0.001)$ \\
\hline
\end{tabular}




\section{FORECAST PRECISION}

Table 4 presents results of Equation (2). As $\mathrm{H} 3$ predicts, the $\mathrm{b}_{2}$ coefficient is significantly positive $(\mathrm{p}=0.001)$, indicating that Canadian firms issue more precise forecasts in bad news periods than do U.S. firms. Also, the sum of coefficients $b_{2}+$ $\mathrm{b}_{3}$ are significantly positive $(\mathrm{p}=0.001)$, indicating that Canadian firms issue more precise forecasts in good news periods than do U.S. firms. Coefficient $b_{1}$ is significantly positive $(\mathrm{p}=0.003)$ indicating that U.S. firms issue less precise forecasts when earnings are declining. Firm size and regulated industry are insignificant $\left(b_{4}\right.$ and $b_{5}$ respectively), while the degree of technology of the firm $\left(b_{6}\right)$, is significant with a p-value of 0.07 , along with the horizon of the forecast, $\left(b_{7}\right)$, significant with a p-value of 0.001 . In summary, results reported in Table 4 support H3, indicating that Canadian firms issue more precise voluntary earnings forecast than do U.S. firms when institutional differences are taken into consideration.

Table 4

Management Earnings Forecast Frequency in the U.S. and Canada

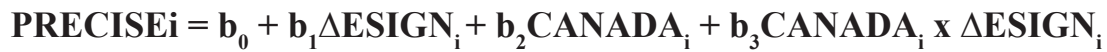
$+b_{4}$ LSIZE $_{i}+b_{5}$ REGULATE $_{i}+b_{6}$ HIGHTECH $_{i}+b_{7}$ HORIZON $_{i}+v_{i}$

\begin{tabular}{|l|l|c|}
\hline \multicolumn{1}{|c|}{$\begin{array}{c}\text { Independent Variable } \\
\text { (Coefficient) }\end{array}$} & \multicolumn{1}{|c|}{ Expected Sign } & $\begin{array}{c}\text { Coefficient Estimate } \\
\text { (p-value) }\end{array}$ \\
\hline Intercept $\left(b_{0}\right)$ & none predicted & $-2.115(0.391)$ \\
\hline$\triangle$ ESIGN $\left(b_{1}\right)$ & positive & $0.272(0.003)$ \\
\hline CANADA $\left(b_{2}\right)$ & positive (H3 for bad news) & $1.310(0.001)$ \\
\hline CANADA $\times \triangle$ ESIGN $\left(b_{3}\right)$ & negative $(H 2)$ & $-0.305(0.311)$ \\
\hline LSIZE $\left(b_{4}\right)$ & negative & $-0.005(0.412)$ \\
\hline REGULATE $\left(b_{5}\right)$ & negative & $-0.298(0.174)$ \\
\hline HIGHTECH $\left(b_{6}\right)$ & none predicted & $-0.153(0.070)$ \\
\hline HORIZON $\left(b_{7}\right)$ & negative & $-0.002(0.001)$ \\
\hline Coefficients $b_{2}+b_{3}$ & positive (H3 for good news) & $0.830(0.001)$ \\
\hline
\end{tabular}




\section{SUMMARY}

This study utilizes one of the largest samples of voluntary earnings forecasts to date, covering a period of over 14 years, to show that institutional differences may characterize why there are differences in the numbers of voluntary forecasts and their associated precision between the U.S, and Canadian firms. Canadian firms have traditionally operated in a less litigious environment, and also were required to adopt IFRS in 2006. These institutional differences may help explain variations in voluntary earnings disclosures between the two countries. This study finds that Canadian managers disclose more earnings forecasts (in both good news and bad news periods) and are more precise in their forecasts than their U.S. counterparts.

Even though Stunda (2012) finds that more U.S. firms issue forecasts after the adoption of Regulation FD, and Stunda (2013) finds the same after adoption of SLUSA, results of these two studies may be mitigated by the overall numbers of firms in Canada that issue forecasts relative to the U.S., especially since the adoption of IFRS in Canada.

The general implication of this study provides a key for stockholders. With respect to disclosure issues, U.S. firms tend to not offer voluntary disclosures as precisely as their Canadian counterparts for the time period studied. In addition, U.S. firms still tend to issue more bad news forecasts than good news forecasts (as seen in extant studies), perhaps out of habit from pre-SLUSA and Regulation FD days, or perhaps because Canadian firms have a stricter requirement from IFRS..

\section{ENDNOTES}

1 The change in earnings is defined as $\left(\mathrm{EPS}_{\mathrm{it}}-\mathrm{EPS}_{\mathrm{it} \mathrm{k}}\right) / \mathrm{PRICE}_{\mathrm{it}-\mathrm{k}}$, where $\mathrm{EPS}_{\mathrm{it}}$ equals earnings per share for firm $\mathrm{i}$ in period, $\mathrm{EPS}_{\mathrm{it-k}}=$ earnings per share for firm $\mathrm{i}$

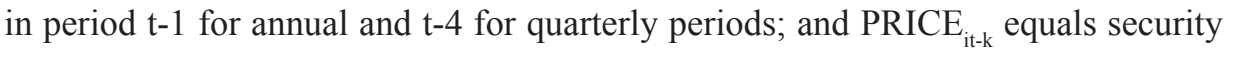
price for firm $i$ at the end of period $t-1$ for annual and $t-4$ for quarterly periods...all obtained from Compustat.

\section{REFERENCES}

Ajinkya, B. B., \& Gift, M. J. (1984). Corporate managers' earnings forecasts and adjustments of Market expectations. Journal of Accounting Research, (2), 425-444.

Baginski, S. P., Hassell, J. M., \& Waymire, G. (1994). Some evidence on the news content of preliminary earnings estimates. The Accounting Review, (1), 265-271.

Baginski, S. P., Hassell, J. M., \& Kimbrough, M. D. (2002). Legal environment and voluntary disclosures. Journal of Accounting Research, 77(1), 25-49. 
Balakrishnan, K, Xi, L., \& Yang, H. (2014) Mandatory financial reporting and voluntary disclosure evidence from mandatory IFRS adoption. Wharton School of Business, 1-53.

Ball, R., S. Kothari, S., \& Robin, A. (2000). The effect of international institutional factors on properties of accounting earnings. Journal of Accounting and Economics, 29(1), 1-52.

Bamber, L. S., \& Cheon, Y. S. (1998). Discretionary management earnings forecast disclosures: Antecedents and outcomes associated with forecast specify choices. Journal of Accounting Research 36 (2), 167-190.

Barth, M. E., \& Clinch. G. (1996). International accounting differences and their relation to share prices: Evidence from U.K., Australian, and Canadian firms. Contemporary Accounting Research 13(1), 135-170.

Bodnar, G. Mm., \& Weintrop, J. (1997). The valuation of foreign income of US multinational firms: A growth opportunities perspective. Journal of Accounting and Economics 24(1), 69-97.

Bodnar, G. M., Hwang, L., \& J. Weintrop (2003). The value-relevance of foreign income: An Australian, Canadian, and British comparison. Journal of International Financial Management \& Accounting, 14(3), 171-193.

Clarkson, P. M., Dontah, A., \& Sefcik, S. E. (1992). The voluntary inclusion of earnings forecasts in IPO prospectuses. Contemporary Accounting Research, 8(2), 601-626.

Diamond, D. W. (1985). Optimal release of information by firms. The Journal of Finance, 40(4), 1071-1094.

Diamond, D. W., \& Verrechia, R. (1987). Constraints on short-selling and asset price adjustments to private information. Journal of Financial Economics, (18), 277-311.

Frank, W. G. (1979). An empirical analysis of international accounting principles. Journal of Accounting Research, 32(2), 137-164.

Frankel, R., McNichols, M., \& Wilson, G. P. (1995). Discretionary disclosures and external financing. The Accounting Review, 70(1), 135-150.

Frost, C. (1994). Accounting disclosure practices in the United States and the United Kingdom. Journal of Accounting Research, 32(1), 75-102.

Guenther, D. A., \& Young, D. (2000). The association between financial accounting measures and real economic activity: A multi-national study. Journal of Accounting and Economics, 29(1), 53-72. 
Harris, T. S., Lang, M., \& Moller, P. H. (1993). The value-relevance of German accounting measures: An empirical analysis. Journal of Accounting Research 32(2), 187-209.

Jacobsen, R., \& Aaker, D. (1993). Management behavior with efficient, but imperfect, financial Markets. Journal of Accounting and Economics 16, 383-405.

Joliet, R., \& Muller, A. (2009). Dividends and foreign performance signaling. Journal of Accounting Research (2), 201-232.

Lees, F. A. (1981). Public disclosure of corporate earnings forecasts. New York, N.Y.: Conference Board, c1981.

Nair, R. D., \& Frank, W. G. (1980). The impact of disclosure and measurement practices on international accounting classifications. Accounting Review, 55(3), 426-450.

Patell, J. M. (1976). Corporate forecasts of earnings per share and stock price behavior: Empirical tests. Journal of Accounting Research, 14(2), 246-276.

Saulter, S. B., \& Doupnik, T. S. (1992). The relationship between legal systems and accounting practices. Advances in International Accounting, 5, 3-22.

Stunda, R.A. (2012). Regulation fair disclosure and its impact on earnings forecasts. International Journal of Business and Social Sciences, 3(17), 2012.

Stunda, R.A. (2013). The effects of the securities litigation uniform standards acts (SLUSA) on earnings forecasts. International Journal of Business, Accounting, \& Finance, Volume 7(2), 97-104.

Waymire, G. (1984). Additional Evidence on the information content of management earnings forecasts. Journal of Accounting Research, 22(2), 703-718.

\section{BIOGRAPHICAL SKETCH OF AUTHOR}

Ronald Stunda is Associate Professor of Accounting at Valdosta State University. He also serves as reviewer for several journals. His research deals mainly with market-based applied accounting research and has appeared in such journals as: Journal of Accounting and Taxation, Academy of Business Journal, Journal of Business and Behavioral Sciences, Advances in Business Research, and the Journal of Accounting and Financial Studies. He can be reached at Valdosta State University, 1500 North Patterson Street, Valdosta, GA, 31698 rastunda@valdosta.edu 